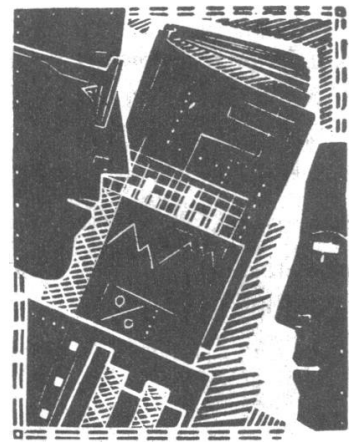

\title{
Effects of feedback of information on clinical practice: a review
}

\author{
Miranda Mugford, Philip Banfield, Moira O’Hanlon
}

Abstract

Objective-To establish what is known about the role of feedback of statistical information in changing clinical practice.

Design-Review of 36 studies of interventions entailing the use of statistical information for audit or practice review, which used a formal research design.

Subjects-Papers identified from computer searches of medical and health service management publications, of which 36 describing studies of interventions designed to influence clinical care and including information feedback from clinical or administrative data systems were reviewed.

Main outcome measures-Evidence for effect of information feedback on change in clinical practice.

Results-Information feedback was most likely to influence clinical practice if it was part of strategy to target decision makers who had already agreed to review their practice. A more direct effect was discernable if the information was presented close to the time of decision making. The questions of the optimum layout and quantity of information were not addressed; the 36 papers were insufficient for defining good formats for information to be used for audit or quality assurance.

Conclusions-Given the cost of information processing and the current emphasis on closing the audit loop in the health services, it is important that the use of information in the audit process should be critically evaluated.

\section{Introduction}

Formal audit of clinical practice is being introduced throughout the NHS, after the NHS Act 1990.' The success of audit may be judged by whether clinical practice moves closer to agreed standards of care. To ascertain whether this is happening both those involved in audit and the professional bodies and policymakers monitoring the impact of audit need statistical data about clinical practice. Recent changes in the NHS have resulted in considerable attention being given to clinical and management computer systems at hospital level for monitoring contracts for services, but the contribution of such systems to clinical audit and the quality of care has yet to be established.

In preparation for a research project designed to explore how data from the clinical obstetric computer system is used in audit in the maternity units in one English health region we reviewed the evidence from health services research about the effects of feedback of information from clinical or administrative data systems on clinical practice.

research fellow

Moira O'Hanlon, BSC,

research assistant

Correspondence to:

Ms Mugford.

BMF 1991;303:398-402
Methods

We identified titles and abstracts of papers from computer literature searches of medical and health service management publications by using the index terms: medical audit, surgical audit, nursing audit, professional review organisations, utilisation review, information systems, and feedback. Related subject areas already reviewed by others cover the overlapping topics of clinical audit, ${ }^{2-6}$ general practice, prescribing, ${ }^{8}$ cost control, ${ }^{9}$ physicians' practice patterns, ${ }^{10}$ and implementation of clinical practice recommendations. ${ }^{11}$ Studies were chosen for this review from the papers identified if they had used a design which either made a historical comparison or used a concurrent control group for comparison.

In reading each paper we looked for evidence of how information was used in the intervention and what the effect was. Information derived from routine health data systems may allow individual clinicians to review their "own" practice over time or may be used to compare colleagues or hospitals. It is this use of comparative information from statistical systems which is generally referred to as "information feedback." Information feedback has been used in different contexts, and passive and active feedback may be distinguished. Passive feedback is the unsolicited provision of information with no stated requirement for action. Active feedback occurs where the interest of clinicians has been engaged in a particular aspect or aspects of practice: standards may have been agreed, the clinicians may be involved in continuing education, or the information may itself be the basis for a discussion about appropriate care.

\section{Results}

We identified 36 published studies of interventions designed to influence clinical care that included the use of statistical data. Tables I-IV summarise the type of intervention and the main results from each of these studies, grouped by the area of health care in which a change in practice was attempted. Twelve studies ${ }^{12-23}$ aimed at altering the use of hospital diagnostic services (table I); five studies ${ }^{2428}$ were concerned with altering the rates of surgical operation (table II); seven ${ }^{29-35}$ with altering the use of prescribed drugs (table III); and the remaining 12 studies $^{36-47}$ examined the effect of educational and information interventions on clinical practice in general practice and hospital and other settings (table IV).

\section{STUDY METHODS}

Sixteen of the studies listed in the tables measured the target behaviour before and after the intervention. A controlled design was used in the 20 other studies, in 12 of which the subjects had been selected as cases or controls by randomisation. Even in randomised designs staff in different groups may communicate, and this might reduce any differences between the groups. In six studies this possibility was minimised by selecting groups which were geographically separated, the members of which were unlikely to meet socially or professionally. ${ }^{19} 30323839+3$ Out of 11 studies in which 
statistical tests were made between control and experimental groups, only four clearly based them on the number of units which they allocated to experimental groups-that is, hospitals, practice groups, or doctors. ${ }^{19}{ }^{3039+1}$ It may be inappropriate to base tests of significance on numbers of patients treated. ${ }^{48}$

\section{PASSIVE FEEDBACK}

The intervention was restricted to passive feedback of statistical information in only four papers. The nearest to this model was the study of Wennberg et al,,$^{25}$ who reported falling tonsillectomy rates in Vermont after presentation of statistics to the Vermont Medical Society. In contrast, no obvious effect was found in a study of the use of biochemical tests in Flinders Medical Centre, South Australia; information was given to clinicians but discussion of the results or decisions on appropriate rates was not required. ${ }^{13} \mathrm{~A}$ controlled study in Tennessee did not show any effect of a commercially designed brochure giving indications for antibiotic prescribing, either on contraindicated prescribing or on prescriptions of oral cephalosporins. ${ }^{30}$

Clinicians lack knowledge about costs of tests and materials. ${ }^{49-51}$ Data on costs of tests may be provided passively by including the information on the test request sheet. This had a short term effect on number of requests for preoperative chest radiographs in one hospital, ${ }^{18}$ but with a changeover of medical house staff, the number returned to that before the study. In another study fewer tests were ordered by physicians when the request forms carried information on their cost ${ }^{15}$ and a similar effect was found more recently with a computerised test ordering system with and without price information available. ${ }^{23}$ When clinical teams were given feedback about charges made to patients for laboratory tests and $x$ ray examinations the effect was less in teams without "an interested leader." 14

\section{ACTIVE FEEDBACK}

In most studies we reviewed, information feedback was preceded or accompanied by a standard setting exercise or other discussion of practice, which might have been educational programmes ${ }^{138394143}$ or professional audit activities ${ }^{182431343742}$ or cost control measures. ${ }^{12-1723}$ In all cases the first stage was to set criteria for the procedure in question, after which the recipients of information are more likely to be alerted to respond to signals of divergence from agreed good practice. This hypothesis is supported by the results of Fowkes's study comparing both active and passive strategies to reduce requests for routine preoperative chest radiography..$^{18}$

TABLE I-Studies of effects of information feedback on use of hospital pathology and radiology services

\begin{tabular}{|c|c|c|c|c|}
\hline Year & Author & Intervention & Research design & Effects \\
\hline 1980 & Martin et al ${ }^{12}$ & $\begin{array}{l}\text { Chart review with discussion of test ordering } \\
\text { patterns }\end{array}$ & Controlled trial & $\begin{array}{l}\text { Long term fall in tests per patient in } \\
\text { experimental group, short term effect in } \\
\text { control group }\end{array}$ \\
\hline 1981 & Grivell et al $l^{13}$ & $\begin{array}{l}\text { Feedback of laboratory use by individual } \\
\text { clinicians }\end{array}$ & $\begin{array}{l}\text { Observation of test use before } \\
\text { and after }\end{array}$ & No significant effects \\
\hline 1982 & Cohen $e t a l^{14}$ & Feedback of cost information to clinicians & Randomised controlled trial & $\begin{array}{l}\text { Short term effect on laboratory use, } \\
\text { reversed at follow up. No clear effect on } \\
\text { radiography requests }\end{array}$ \\
\hline 1982 & Cummings et al" & Test order forms with price information & Randomised controlled trial & $\begin{array}{l}\text { Use of tests reduced in group with prices } \\
\text { on order form }\end{array}$ \\
\hline 1983 & Everett $e t a l^{\text {is }}$ & $\begin{array}{l}\text { (a) Feedback of cost and use of tests } \\
\text { (b) Chart review and discussion, with feedback } \\
\text { as in }(a)\end{array}$ & $\begin{array}{l}\text { Randomised controlled trial by } \\
\text { patient, ward, and medical } \\
\text { team }\end{array}$ & $\begin{array}{l}\text { (a) No significant effect } \\
\text { (b) Reduced test use in intervention group }\end{array}$ \\
\hline 1984 & Schroeder $e t a l^{17}$ & $\begin{array}{l}\text { (a) Lectures on cost containment with feedback } \\
\text { of patients' bills } \\
\text { (b) Chart audit with feedback on tests ordered } \\
\text { (c) }(a)+(b)\end{array}$ & $\begin{array}{l}\text { Controlled trial; patients } \\
\text { randomly allocated to medical } \\
\text { firm }\end{array}$ & $\begin{array}{l}\text { Very little effect; }(c) \text { showed most } \\
\text { difference }\end{array}$ \\
\hline 1985 & Fowkes $^{18}$ & $\begin{array}{l}\text { Circulation of guidelines for use of preoperative } \\
\text { radiography to all. Then } \\
\text { (a) Utilization review committee } \\
\text { (b) Information feedback } \\
\text { (c) New request form } \\
\text { (d) Concurrent review by radiology department }\end{array}$ & Controlled study by hospital & $\begin{array}{l}\text { Significant fall in preoperative } \\
\text { radiography requests between baseline } \\
\text { period and final month of study in }(a)+ \\
(b) \text {, and no change in control hospitals }\end{array}$ \\
\hline 1986 & $\begin{array}{l}\text { Chassin and } \\
\text { McCue'19 }\end{array}$ & $\begin{array}{l}\text { Agreement on criteria for pelvimetry by } \\
\text { intervention group. Educational programme } \\
\text { monthly feedback about pelvimetry rates }\end{array}$ & $\begin{array}{l}\text { Randomised controlled trial by } \\
\text { professional standards review } \\
\text { organisations or hospital } \\
\text { within review organisations }\end{array}$ & $\begin{array}{l}\text { Intervention group pelvimetry rate fell } \\
\text { faster than in control group and } \\
\text { difference was sustained }\end{array}$ \\
\hline 1987 & Wones $^{20}$ & Low cost audit with feedback about use of tests & Observation before and after & No change in ordering \\
\hline 1988 & Finn $e t a l^{11}$ & $\begin{array}{l}\text { Alteration of physicians' test orders by support } \\
\text { staff }\end{array}$ & Observational & $\begin{array}{l}\text { Inappropriate tests were less common for } \\
\text { patients for whom non-physicians } \\
\text { queried orders }\end{array}$ \\
\hline 1989 & $\begin{array}{l}\text { Pop and } \\
\quad \text { Winkens }{ }^{22}\end{array}$ & $\begin{array}{l}\text { Twice yearly feedback to GPs about requests for } \\
\text { diagnostic tests, with specialist comment }\end{array}$ & $\begin{array}{l}\text { Before and after observations of } \\
\text { test use }\end{array}$ & $\begin{array}{l}\text { Overall reduction in use of unnecessary } \\
\text { tests. GPs with low rates of ordering } \\
\text { likely to react most positively to } \\
\text { protocols for use of tests }\end{array}$ \\
\hline 1990 & Tierney $^{23}$ & $\begin{array}{l}\text { Financial ordering of tests with and without } \\
\text { costings }\end{array}$ & Randomised controlled trial & $\begin{array}{l}\text { Displaying charges reduced number and } \\
\text { cost of tests ordered but effect did not } \\
\text { last when intervention discontinued }\end{array}$ \\
\hline
\end{tabular}

TABLE II-Studies of effects of information feedback on operative procedures

\begin{tabular}{|c|c|c|c|c|}
\hline Year & Author & Intervention & Research design & Effects \\
\hline 1977 & Dyck $e t a l^{44}$ & $\begin{array}{l}\text { Committee review of rates of hysterectomy in } \\
\text { seven hospitals. Press coverage about excess } \\
\text { hysterectomy }\end{array}$ & Prospective, no controls & $\begin{array}{l}\text { Overall rates and the proportion done for } \\
\text { "unacceptable" reasons fell }\end{array}$ \\
\hline 1977 & Wennberg et al ${ }^{2}$ & $\begin{array}{l}\text { Presentation to state medical societv about } \\
\text { differences in tonsillectomy among hospitals }\end{array}$ & $\begin{array}{l}\text { Observation of trends in } \\
\text { practice }\end{array}$ & $\begin{array}{l}\text { Fall in rates, greatest in hospital with peer } \\
\text { review }\end{array}$ \\
\hline 1980 & Gleicher $^{26}$ & $\begin{array}{l}\text { National consensus development conference on } \\
\text { caesarean section }\end{array}$ & $\begin{array}{l}\text { Observation of practice after } \\
\text { conference }\end{array}$ & No fall in rates \\
\hline 1988 & $\begin{array}{l}\text { Myers and } \\
\text { Gleicher }^{27}\end{array}$ & Audit of caesarean section in one hospital & Before and after & $\begin{array}{l}\text { Rate of caesarean section fell with no } \\
\text { increase in operative vaginal delivery or } \\
\text { other adverse outcomes }\end{array}$ \\
\hline 1989 & Lomas et a $l^{28}$ & $\begin{array}{l}\text { Guidelines for caesarean section from consensus } \\
\text { development task force }\end{array}$ & $\begin{array}{l}\text { Observation of knowledge of } \\
\text { guidelines and change in } \\
\text { practice after publication }\end{array}$ & $\begin{array}{l}\text { One third reported change in practice; one } \\
\text { third had incorrect knowledge of } \\
\text { guidelines. Actual practice differed } \\
\text { from that reported and did not show } \\
\text { reported effect }\end{array}$ \\
\hline
\end{tabular}




\begin{tabular}{|c|c|c|c|c|}
\hline Year & Author & Intervention & Research design & Effects \\
\hline 1983 & $\begin{array}{l}\text { Mersey Regional } \\
\text { Health } \\
\text { Authority }{ }^{29}\end{array}$ & $\begin{array}{l}\text { Letter with information and recommendations } \\
\text { for prescribing }\end{array}$ & Observational & $\begin{array}{l}\text { Changes in prescribing patterns, } \\
\text { reflecting advice in letters }\end{array}$ \\
\hline 1983 & Schaffner $e t a l^{30}$ & $\begin{array}{l}\text { Comparison of } 3 \text { strategies to alter antibiotic } \\
\text { prescribing } \\
\text { (a) mailed brochure } \\
\text { (b) visit by drug educator } \\
\text { (c) visit by physician }\end{array}$ & Controlled study by physician & $\begin{array}{l}\text { No effect of brochure (physician visit had } \\
\text { an effect) }\end{array}$ \\
\hline 1984 & Harris et $a l^{31}$ & $\begin{array}{l}\text { Feedback to GPs about number and cost of } \\
\text { prescriptions; meetings for discussion }\end{array}$ & Controlled study by GP group & $\begin{array}{l}\text { Intervention groups' prescription rates } \\
\text { per patient fell more than those of } \\
\text { control group }\end{array}$ \\
\hline 1985 & Grant $e t a l^{32}$ & $\begin{array}{l}\text { Limited formulary agreed by intervention } \\
\text { group }\end{array}$ & $\begin{array}{l}\text { Controlled study by GP groups; } \\
\text { teaching GPs in study group, } \\
\text { non-teaching GPs as controls }\end{array}$ & $\begin{array}{l}\text { Control group prescribed much higher } \\
\text { proportion of drugs not in formulary }\end{array}$ \\
\hline 1987 & Whiteside $e t a l^{33}$ & $\begin{array}{l}\text { Educational guidelines on appropriate use of } \\
\text { cephalosporins inserted in patient records }\end{array}$ & $\begin{array}{l}\text { Observation of prescribing } \\
\text { before and after }\end{array}$ & $\begin{array}{l}\text { Change of prescription for } 28 \% \text { of patients } \\
\text { within } 48 \mathrm{~h} \text { of intervention }\end{array}$ \\
\hline 1988 & Anderson et $a l^{\mu}$ & $\begin{array}{l}\text { Analysis and feedback of data about digoxin to } \\
\text { GP principals in } 5 \text { practices. Feedback } \\
\text { included comparisons with "expert" protocol } \\
\text { for digoxin use }\end{array}$ & $\begin{array}{l}\text { Practice of those receiving } \\
\text { feedback versus those in same } \\
\text { practices not receiving } \\
\text { feedback }\end{array}$ & $\begin{array}{l}\text { Record keeping for pulse measurement } \\
\text { increased in intervention group but not } \\
\text { in control group }\end{array}$ \\
\hline 1989 & Parrino ${ }^{35}$ & $\begin{array}{l}\text { Automated peer comparison feedback to } \\
\text { attending physicians with higher than median } \\
\text { costs for one year's antibiotic prescriptions }\end{array}$ & $\begin{array}{l}\text { Observation of prescribing } \\
\text { before and after. Comparison } \\
\text { with unspecified control } \\
\text { group }\end{array}$ & $\begin{array}{l}\text { No reduction in prescribing costs or use of } \\
\text { antibiotics }\end{array}$ \\
\hline
\end{tabular}

TABLE IV Studies of effects of information feedback on other aspects of clinical care

\begin{tabular}{|c|c|c|c|c|}
\hline Year & Author & Intervention & Research design & Effects \\
\hline 1976 & Nelson $^{36}$ & $\begin{array}{l}\text { Introduction of supra-hospital professional } \\
\text { review programme; feedback of statistical } \\
\text { data }\end{array}$ & Observational & $\begin{array}{l}\text { Reaction to "bad" results was to query } \\
\text { data or criteria }\end{array}$ \\
\hline 1978 & Morgan et al $l^{3 ?}$ & $\begin{array}{l}\text { Concurrent review of computer records of } \\
\text { antenatal care for compliance with American } \\
\text { College of Obstetricians and Gynecologists' } \\
\text { standards, immediate feedback to physicians }\end{array}$ & $\begin{array}{l}\text { Alternate allocation of patients } \\
\text { to have computer record } \\
\text { reviewed or not }\end{array}$ & $\begin{array}{l}\text { Compliance with standards was higher } \\
\text { when patient record was reviewed. In } \\
\text { subsequent } 12 \text { months care of control } \\
\text { group improved to same level }\end{array}$ \\
\hline 1980 & $\operatorname{Linn}^{3 x}$ & $\begin{array}{l}\text { Educational package with feedback about } \\
\text { compliance with preagreed criteria for } \\
\text { emergency burn treatment }\end{array}$ & $\begin{array}{l}\text { Randomised controlled trial by } \\
\text { hospital }\end{array}$ & $\begin{array}{l}\text { Improved care in intervention group; no } \\
\text { change in controls }\end{array}$ \\
\hline 1982 & Sibley $e t a l^{39}$ & $\begin{array}{l}\text { Educational packages for GPs with feedback on } \\
\text { compliance with treatment criteria }\end{array}$ & $\begin{array}{l}\text { Randomised controlled trial by } \\
\text { GP }\end{array}$ & $\begin{array}{l}\text { In topics for which GPs expressed interest } \\
\text { control group improved as much as } \\
\text { study group. Differential imrovement } \\
\text { for in study group for topics for which } \\
\text { GPs expressed little interest }\end{array}$ \\
\hline 1983 & Schlager" & $\begin{array}{l}\text { Computer medical summaries for patients of } \\
\text { GPs }\end{array}$ & $\begin{array}{l}\text { Observation of compliance with } \\
\text { treatment and health } \\
\text { outcomes before and after }\end{array}$ & $\begin{array}{l}\text { Compliance with "health maintenance" } \\
\text { advice increased; no change in blood } \\
\text { pressure for people with chronic } \\
\text { hypertension }\end{array}$ \\
\hline 1985 & Cohen $e t a t^{41}$ & $\begin{array}{l}\text { Reading material targeted to specific } \\
\text { preventive care practice recommendations }\end{array}$ & Randomised controlled trial & $\begin{array}{l}\text { Those compliant before became more } \\
\text { compliant. Less effect with group that } \\
\text { needed most change }\end{array}$ \\
\hline 1985 & $\begin{array}{l}\text { Norton and } \\
\text { Dempsey }\end{array}$ & $\begin{array}{l}\text { Standards for treatment of cystitis and vaginitis } \\
\text { set by individual physicians who received } \\
\text { immediate feedback about performance }\end{array}$ & Crossover design & $\begin{array}{l}\text { Significant improvements in practice were } \\
\text { seen with the intervention }\end{array}$ \\
\hline 1986 & Evans $e t a l^{43}$ & $\begin{array}{l}\text { Fourteen weekly instalments of educational } \\
\text { material about antihypertensive care to } \\
\text { primary care physicians }\end{array}$ & $\begin{array}{l}\text { Randomised controlled trial by } \\
\text { GP }\end{array}$ & $\begin{array}{l}\text { Study group patients more likely to have } \\
\text { blood pressure check. Patients in both } \\
\text { groups received more medication. } \\
\text { Physicians in both groups had same } \\
\text { score in test of knowledge }\end{array}$ \\
\hline 1987 & $\begin{array}{l}\text { Braham and } \\
\text { Ruchlin }\end{array}$ & $\begin{array}{l}\text { Computerised feedback of information to those } \\
\text { who make decisions generating costs in } \\
\text { ambulatory care }\end{array}$ & $\begin{array}{l}\text { Observation of charges before } \\
\text { and after }\end{array}$ & Reduction in charges for services \\
\hline 1989 & McPhee et als & $\begin{array}{l}\text { Three methods to increase uptake of seven } \\
\text { cancer screening tests. Resident doctors were } \\
(a) \text { given reminders about patients not } \\
\text { screened, }(b) \text { involved in audit meetings with } \\
\text { feedback }(c) \text { controls. Patients of half the } \\
\text { doctors in }(a),(b), \text { and }(c) \text { were given } \\
\text { information about } 2 \text { tests and notice of } \\
\text { overdue tests }\end{array}$ & Randomised controlled trial & $\begin{array}{l}\text { Intervention }(a) \text { increased uptake of } 6 \text { out } \\
\text { of } 7 \text { tests. Intervention }(b) \text { increased } \\
\text { uptake of } 4 \text { tests. Patient education } \\
\text { improved uptake in one of two tests. }\end{array}$ \\
\hline 1989 & Weingarten $e^{2} \mathrm{al}^{\text {th }}$ & $\begin{array}{l}\text { Computerised protocol to prompt action on } \\
\text { preventive measures in family practice }\end{array}$ & $\begin{array}{l}\text { Randomised controlled trial. } \\
\text { Patients randomised to } \\
\text { computer or manual record }\end{array}$ & $\begin{array}{l}\text { Recording of key items increased for both } \\
\text { groups of patients. Computer group had } \\
\text { more items recorded and longer } \\
\text { consultation times. Less improvement } \\
\text { for items requiring frequent } \\
\text { measurement. }\end{array}$ \\
\hline 1990 & $\begin{array}{l}\text { Swor and } \\
\text { Hoelzer }^{7}\end{array}$ & $\begin{array}{l}\text { Computer assisted quality assurance for } \\
\text { emergency medical services by paramedics }\end{array}$ & $\begin{array}{l}\text { Observation of compliance with } \\
\text { protocol before and after } \\
\text { quality assurance }\end{array}$ & Improvement in compliance with protocol \\
\hline
\end{tabular}

The level at which standard setting takes place may be important. For example, Nelson observed that data presented by the suprahospital professional review programme were not trusted by the clinicians. ${ }^{36}$ Gleicher suggested that as caesarean section rates had not fallen in the United States since the national consensus development conference reported in 1980, their control in the United States must require peer review by individual physicians as well as nationally, ${ }^{26}$ and he subsequently showed the effectiveness of such a policy in his own hospital. ${ }^{27}$ In Canada Lomas $e t a l^{28}$ found that knowledge of the consensus conference guidelines on indications for caesarean section remained poor, even with intensive circulation to practising clinicians. They emphasised the role of incentives, or removal of disincentives, in implementing changes in practice and also made the point that clinicians were often mistaken in their beliefs about their own practice patterns.

Six of the studies used data on tests that had been ordered, hospital costs, or prescriptions as a basis for discussing appropriate practice with the groups of clinicians involved, ${ }^{12}{ }^{13} 16-1831$ and in most cases this was effective in changing patterns of target behaviour in the short term.

When we examined trials of educational strategies to 
inform clinicians about "best" evidence for managing common disorders in primary care the effect on practice was not clear. Sibley et al found the strongest effect of continuing education was in aspects of care for which family physicians had previously indicated a lack of interest. ${ }^{39}$ Evans et al failed to detect any effect on knowledge or practice of a postal educational programme on management of hypertension. ${ }^{43}$ In another controlled trial whose aim was to improve adherence to standards for care, reading material was sent to residents in internal medicine.$^{41}$ Physicians who were already compliant were more likely to improve their practice than those whose practice deviated most from the recommended standards before the trial.

\section{WHO RECEIVES THE INFORMATION?}

Making sure that information reaches the right people is important. Braham and Ruchlin ${ }^{4+}$ identified the people responsible for decisions about use of resources in ambulatory care and found that giving them information about their use of services reduced overall patient charges. In studies of general practice individual general practitioners are responsible for their own decisions and are thus the appropriate target for education or information feedback. Harris et al aimed their intervention at practice level as well as at individual general practitioners, ${ }^{31}$ as discussions and policy at practice level may well affect individual decisions. In hospital, policies may be set at consultant level but are usually put into practice by junior staff. When information was sent only to consultants, as in Fowkes's study of the use of preoperative chest radiography ${ }^{18}$ communication between senior and junior staff was being tested additionally. On the other hand, studies that concentrated only on junior staff, as was common in many of the American studies of laboratory use, found that the effect of the intervention was strengthened when senior staff were brought into the audit process.

Although we concentrated on the clinician as decision maker and therefore as the appropriate recipient of information, this focus may be inappropriate when other professionals are involved in care. In the studies by Finn $e t a l^{1}$ and Swor and Hoelzer ${ }^{47}$ non-medical staff with access to information influenced practice patterns. Public opinion may also influence the decisions made about types of care, and patients may take an active part in the choice of particular options. ${ }^{24}$ The effect of public awareness of surgical intervention rates was illustrated in Switzerland..$^{52}$ The high rate of hysterectomy in the canton of Ticino compared with the rates in the United Kingdom and Norwegian health regions was widely publicised during nine months. Subsequently the rate fell sharply in Ticino and remained low. In the neighbouring canton of Bern where there was no publicity, the rate of hysterectomy did not change. Williams and Chen suggested that caesarean section rates might be similarly controlled..$^{53}$

\section{WHAT FORMAT SHOULD THE INFORMATION TAKE?}

The reviewed papers contained relatively little about the quantity or format of the data presented or about how recipients interpreted the feedback. None of the studies formally compared the effects of different formats for presenting information, but three factors may be especially important: numbers versus graphs, quantity of data, and computer screen versus paper.

The methods of presentation described varied between cost data from laboratories presented as weekly listings of tests ordered ${ }^{14}$ to histograms showing the position of an individual clinician in relation to his or her colleagues. ${ }^{13}$ The quantity of data presented was variable: Nelson described tables showing the degree of accord with standard criteria for hospital treatments in 120 diagnostic related groups. ${ }^{36}$ Harris et al described tables from routine analysis of prescriptions, running to many pages for each general practitioner, accompanied by practice summaries and occasional graphs and tables of national data for comparison. ${ }^{31}$ They showed a shift over time in which tables interested general practitioners most. Five of the studies reviewed evaluated the effects of some form of online prompts to practitioners by computerised recording or ordering systems. ${ }^{374044647}$ The results of these studies all suggested that this may be an effective medium for influencing practice.

\section{HOW DOES TIMING OF FEEDBACK AFFECT PRACTICE?}

The studies varied considerably in the timing and frequency of information feedback. For example, Linn described feedback after 48 hours about the quality of an individual clinician's treatment of patients with burns. ${ }^{38}$ Many laboratory test studies in the United States included weekly feedback of test use and costs. Delay may occur when data are collected manually or are abstracted from case notes or have to be processed to provide a special output from routine systems. Data were fed back twice in a year in Fowkes's study of requests for preoperative chest radiography ${ }^{18}$ and twice a year for two years in the study of Harris et al..$^{31}$

During the period of this review the possibilities for almost instantaneous feedback with computer information systems have been developing, and all of the five relevant studies suggested that concurrent reminders of costs or protocols for treatment increased compliance with standards. ${ }^{374044647}$

\section{VALIDATION OF STATISTICAL DATA}

The quality of data and choice of specific indicators are often criticised when feedback from routine statistical systems is attempted. Nelson mentioned such criticism by medical staff at hospitals in the Utah Professional Standards Review Organisation. ${ }^{36}$ Although not widely mentioned in the British studies, mistrust of routinely collected data is fairly widespread in the NHS..$^{54}$ Harris et al encouraged general practitioners to ask for additional data or for clarification of what they had received, and they responded by requesting further data about specific topics. ${ }^{31}$

\section{Discussion}

We found that feedback of information is necessary but not sufficient in the process of maintaining high quality clinical care. This review supports previous conclusions that feedback of information most probably influences clinical practice if it is part of an overall strategy which targets decision makers who have already agreed to review their practice. Information feedback is likely to have a more direct effect on practice if presented close to the time of decision making. We did not find answers to the questions of optimum layout and quantity of information, although these factors may significantly affect the interpretation of numerical data. ${ }^{55}$ The introduction of clinical audit should improve access to data on clinical care and its quality. However, in the NHS the link between those responsible for routine data collection systems and those concerned with clinical research, audit, and practice review is often tenuous. In particular, as the health service and its information become more disaggregated it is uncertain whether data will be available for comparing care in different places within England.

Barr $^{56}$ and Mitchell and Fowkes ${ }^{57}$ recommended that methods for feedback of information about practice or performance should be assessed experimentally over a sufficient time to establish whether change, if it occurs at all, is only transient. Wennberg suggested that variations in practice reflect uncertainty and disagreement about what constitutes appropriate care ${ }^{58}$ Health 
authorities in Britain now have audit committees and audit assistants, but their roles are not yet clear. The official view of audit given in a recent health circular seems to suggest that though medical audit may identify the need for change in practice, continuing education would be the means to bring about that change. ${ }^{1}$ The evidence supporting this premise is not strong or encouraging, and the use of educational methods would also need careful and controlled evaluation. The papers we reviewed suggest, for example, that postal education packages may influence practice less than prompts about treatment protocols given to clinicians at the time of a consultation. It is important for those who use the health services that the feedback loop of standard setting, information collection, review, and change in practice be completed. In the wake of the most recent NHS Act considerable efforts and resources are being used for that purpose, but less effort seems to be spent in establishing whether these resources are being used to best effect.

We thank colleagues in the National Perinatal Epidemiology Unit and the department of obstetrics and gynaecology at St Mary's Hospital Medical School for their advice on earlier drafts of this paper. MM is funded by the Department of Health. PB and MO'H are jointly funded by the Department of Health and North West Thames Regional Health Authority.

1 Department of Health. Medical audit in the hospital and community healt services. London: $\mathrm{DoH}, 1991$. (HC(91)2.)

2 Shaw CD. Aspects of audit. I. The background. BMF 1980;280:1256-8.

3 Shaw CD. Aspects of audit. II. Audit in British hospitals. BMJ 1980;280 $1314-5$.

4 Shaw CD. Aspects of audit. III. Audit in British general practice. $B M$ 1980;280:1361-3.

5 Shaw CD. Aspects of audit. IV. Acceptability of audit. BMF 1980;280:1443-6.

6 Shaw CD. Aspects of audit. V. Looking forward to audit. BMJ 1980;280: $1509-11$.

7 Horder J, Bosanquet N, Stocking B. Ways of influencing the behaviour of general practitioners. $\mathcal{f} R$ Coll Gen Pract 1986;36:517-21.

8 Hemminki E. Factors influencing drug prescribing - inquiry into research strategy. Drug Intelligence and Clinical Pharmacy 1976;10:321-9.

9 Grossman RM. A review of cost-containment strategies for laboratory testing. Med Care 1983;21:783-802.

10 Eisenberg JM. Physician utilization. The state of research about physicians' practice patterns. Med Care 1985;23:461-83.

11 Lomas J, Haynes RB. A taxonomy and critical review of tested strategies for the application of clinical practice recommendations: from "official" to "individual" clinical policy. Am $\mathcal{f}$ Prev Med 1988;suppl 4:77-94.

12 Martin AR, Wolf MA, Thibodeau LA, Dzau V, Braunwald E. A trial of two strategies to modify the test ordering behavior of medical residents. New Engl f Med 1980;303:1330-6.

13 Grivell AR, Forgie HJ, Fraser CG, Berry MN. Effect of feedback to clinical staff of information on clinical biochemistry requesting patterns. Clin Chem 1981;27:1717-20.

14 Cohen DI, Jones P, Littenberg B, Newhauser D. Does cost information availability reduce physician test usage? Med Care 1982;20:286-92.

15 Cummings KF, Frisof KB, Long MJ, Hrynkiewich G. The effects of price information on physicians' test ordering behaviour. Med Care 1982;20:293 301.

16 Everett GC, De Blois S, Chang PF, Hollets T. Effect of cost education, cost audits and faculty chart review on the use of laboratory services. Arch Intern Med 1983;143:942-4.

17 Schroeder SA, Myers L.P, McPhee SJ, Showstack JA, Simborg DW, Chapman $\mathrm{SA}$, et al. The failure of physician education as a cost containment strategy. SAMA 1984;252:225-30.

18 Fowkes FGR. Strategies for changing the use of diagnostic radiology. London: King's Fund, 1985. King's Fund project paper No 57.

19 Chassin MR, McCue SM. A randomised controlled trial of medical quality assurance: improving physicians' use of pelvimetry. JAMA 1986;256: $1012-6$

20 Wones RG. Failure of low-cost audits with feedback to reduce laboratory test utilization. Med Care 1987;25:78-82.

21 Finn AF, Valenstein PN, Burke MD. Alteration of physicians' orders by nonphysicians. JAMA 1988;259:2549-52.

22 Pop P, Winkens R. A diagnostic centre for general practitioners: results of individual feedback on diagnostic actions. I $R$ Coll Gen Pract 1989;39: 507-8.
23 Tierney WM, Miller ME, McDonald CJ. The effect on test ordering of informing physicians of the charges for outpatient diagnostic tests. New Engl f Med 1990;322:1499-504.

24 Dyck FJ, Murphy FA, Murphy JK, Road DA, Boyd MS, Osborne E, et al. Effect of surveillance of the number of hysterectomies in the province of Effect of surveillance of the number of hysterectom
Saskatchewan. New Engl f Med 1977;296:1326-8.

25 Wennberg JE, Blowers L, Parker R, Gittelsohn AM. Changes in tonsillectomy rates associated with feedback and review. Pediatrics 1977;59:821-6.

26 Gleicher N. Cesarean section rates in the United States. The short term failure of the national consensus development conference in 1980. JAMA 1984;252:3273-6

27 Myers SA, Gleicher N. A successful program to lower cesarean section rates. New Engl f Med 1987;319:1511-6.

28 Lomas J, Anderson GM, Domnick-Pierre K, Vayda E, Enkin MW, Hannah WJ. Do practice guidelines guide practice? New Engl 3 Med 1989;321: 1306-11.

29 Mersey Regional Drug Information Service. An assessment of whether the rational and economic use of drugs can be influenced by the Drug Information Service. Liverpool: Mersey Regional Health Authority, 1983. (JR 124/334.)

30 Schaffner W, Ray WA, Federspiel CF, Miller WO. Improving antibiotic prescribing in office practice. A controlled trial of three educational methods. JAMA 1983;250:1728-32.

31 Harris CM, Jarman B, Woodman E, White P, Fry JS. Prescribing - a suitable case for treatment. London: RCGP, 1984. (Occasional paper No 24.)

32 Grant GP, Gregory DA, Van Zwannenberg TD. Development of a limited formulary for general practice. Lancet 1985;i:1030-2.

33 Whiteside ME, Lefkowitz S, Justiniani FR, Ratzan K. Changing practice patterns, a program of physician education. Hospital Formulary 1987;22: 561-3,566,568.

34 Anderson CM, Chambers S, Clamp M, Dunn I, McGhee M, Sumner K, et al. Can audit improve patient care? Effects of studying use of digoxin in general practice. $B M 7$ 1988;297:113-4.

35 Parrino TA. The non-value of retrospective peer comparison feedback in containing hospital antibiotic costs. Am I Med 1989;86:442-8.

36 Nelson AR. Orphan data and the unclosed loop. A dilemma in PSRO and medical audit. New Engl f Med 1976;295:617-9.

37 Morgan M, Studney DR, Barnett GO, Winickoff RN. Computerized concurrent review of prenatal care. $Q R B$ 1978;4:33-6.

38 Linn BS. Continuing medical education: impact on emergency room burn care. JAMA 1980;244:565-70

39 Sibley JC, Sackett DL, Neufeld V, Gerrard B, Rudnick KV, Fraser W. A randomised trial of continuing medical education. New Engl $\mathcal{f}$ Med 1982;306:511-5.

40 Schlager DD. A comprehensive patient care system for the family practice. f Med Syst 1983;7:137-45.

41 Cohen SJ, Weinberger M, Hui SL, Tierney WM, McDonald CJ. The impact of reading on physicians' nonadherence to recommended standards of medical care. Soc Sci Med 1985;21:909-14.

42 Norton PG, Dempsey LJ. Self-audit: its effect on quality of care. 7 Fam Pract 1985;21:289-91

43 Evans CE, Haynes RB, Birkett NJ, Gilbert JR, Taylor DW, Sackett DL, et al. Does a mailed continuing education programme improve physician performance? Results of a randomized controlled trial in antihypertensive care. IAMA 1986;255:501-4.

44 Braham RL, Ruchlin HS. Physician practice profiles: a case study of the use of audit and feedback in an ambulatory care group practice. Health Care Manage Rev 1987;12:11-6.

45 McPhee SJ, Bird JA, Jenkins CN, Fordham D. Promoting cancer screening. A randomised controlled trial of three interventions. Arch Intern Med 1989;149:1866-72.

46 Weingarten MA, Bazel D, Shannon HS. Computerized protocol for preventive medicine, a controlled self audit in family practice. Fam Pract 1989;6:120-4

47 Swor RA, Hoelzer M. A computer assisted quality assurance in a multiprovider EMS system. Ann Emerg Med 1990;19:286-90.

48 Whiting-O'Keefe QE, Henke C, Simborg D. Choosing the correct unit of analysis in medical care experiments. Med Care 1984;22:1101-14.

49 Fowkes FGR. Doctors' knowledge of the costs of medical care. Med Educ 1985;19:113-7.

50 Wynick D, Jessop JH. A survey of cost awareness among hospital medical staff. Health Trends 1985;17:24.

51 Long MJ, Cummings KM, Frisof KB. The role of perceived price in physicians' demand for diagnostic tests. Med Care 1983;21:243-50.

52 Domenighetti G, Luraschi P, Casabianca A, Gutzwiller F, Spinelli A, Pedrinis $\mathrm{E}$, et al. Effect of information campaign by the mass media on hysterectomy E, et al. Effect of information
rates. Lancet 1988;ii:1470-3.

53 Williams RL, Chen PM. Controlling the rise in cesarean section rates by dissemination of information from vital records. Am $\mathcal{f} P u b l$ Health 1983;73:863-7.

54 Sunderland R. Inaccurate coding corrupts medical information. Arch Dis Child 1985;60:593-4.

55 Macdonald-Ross $M$. How numbers are shown: a review of research on the presentation of quantitative data in texts. Audio-visual Communication Review 1977;25:359-409.

56 Barr A. Measuring hospital performance: a proposed limited experiment. Hospital and Health Services Review 1986;82:70-1.

57 Mitchell MW, Fowkes FGR. Audit reviewed. Does feedback on performance change clinical behaviour? $\mathcal{F} R$ Coll Physicians Lond 1985;19:251-4.

58 Wennberg JE. Dealing with medical practice variations: a proposal for action. Health Aff (Millwood) 1984;3:6-32.

(Accepted 17 May 1991) 